DOI: https://doi.org/10.35387/ucj.2(2).2020.24-29

ANNA TOVKANETS

\title{
UNIVERSITY AND LIFELONG EDUCATION IN THE EUROPEAN EDUCATIONAL SPACE: THE INTERDEPENDENCE OF GOALS AND STRATEGIES
}

\begin{abstract}
The article analyzes the interdependence of goals and strategies of university education and lifelong learning in the European educational space. The aim of the article is to substantiate the interaction of university education and lifelong learning and to determine their role in the modern European social space. The research is carried out on the basis of methods of theoretical generalization, comparative analysis; methods of grouping and systematization. It was emphasized that the rethinking of social tasks, the need to adapt to the expectations of society, the growth of the demand for future skills motivate university education at the beginning of the 21st century to prepare a successful professional who is focused on the continuous updating and replenishment of knowledge, skills and abilities. It is revealed that in modern conditions in university and lifelong education the emphasis is on the formation of such competencies as an optimistic view of life situations, that is, the ability to adapt and interact effectively in the growing demands of volatile and uncertain social environments, the ability to analytically process large amounts of data, detection of algorithms, prediction of dynamics, ability to model optimal production processes and environments for systematically achieving desired results in each individual situation, ability to establish direct and deep interpersonal connections, ability to recognize causes and consequences of key trends, notice tendencies on the periphery of social systems. It is concluded that today more and more the question arises about the need to expand the scope of universities and their exit beyond the two-dimensional classical model, which includes educational activities and scientific research and the social purpose of universities, and within their framework and education throughout their lives, the direction and formation of socially important competencies.
\end{abstract}

Key words: higher education, university education, life-long education, educational space, competence, European society, criteria of effectiveness.

\section{УНІВЕРСИТЕТСЬКА ОСВІТА І ОСВІТА ВПРОДОВЖ ЖИТТЯ В ЄВРОПЕЙСЬКОМУ ОСВІТНЬОМУ ПРОСТОРІ: ВЗАЄМООБУМОВЛЕНІСТЬ ЦІЛЕЙ І СТРАТЕГІЙ}

\begin{abstract}
Анотація. В статті здійснено аналіз взаємообумовленості цілей і стратегій університетської освіти і освіти впродовж життя в європейському освітньому просторі. Мета статті полягає у обгрунтуванні взаємовпливу університетської освіти і освіти впродовж життя та визначенні їх ролі у сучасному європейському соціальному просторі. Дослідження здійснено на основі методів теоретичного узагальнення; порівняльного аналізу; методів групування і систематизації. Наголошено, що переосмислення суспільних завдань, необхідність адаптації до очікувань суспільства, зростання попиту на формування навичок майбутнього спонукають університетську освіту на початку ХХІ століття до підготовки успішного професіонала, який зорієнтований на безперервне оновлення і поповнення знань, умінь, навичок. Виявлено, що в сучасних умовах в універсистеській освіті й освіті впродовж життя акцент зроблено на формуванні таких компетентностей, як оптимістичний погляд на життєві ситуації, тобто здатність адаптуватися та ефективно взаємодіяти в умовах зростаючих вимог непостійних та невизначених соціальних середовищ, здатність до аналітичного опрацювання великих обсягів даних, виявлення алгоритмів, прогнозування динамік, вміння моделювати оптимальні виробничі процеси й середовища задля системного досягнення бажаних результатів в кожній індивідуальній ситуації, здатність встановлювати прямі та глибокі міжособистісні зв'язки, здатність розпізнавати причини та наслідки ключових трендів, помічати тенденційні процеси на периферії соціальних систем. Зроблено висновок, що сьогодні все частіше постає питання про необхідність розширення сфери діяльності університетів і їх виходу за межі двомірної класичної моделі, що включає освітню діяльність і наукові дослідження, та соціальної призначеності університетів, а в їх рамках і освіти впродовж життя, спрямування на формування соціально важливих компетентностей.
\end{abstract}

Ключові слова: вища освіта, університетська освіта, освіта впродовж життя, освітній простір, компетентності, європейське суспільство, критерії ефективності. 
Introduction. At the beginning of the XXI century the role of higher education is defined in the context of the implementation of such interrelated aspects as the knowledge society and education; connection of entrepreneurship, higher education and social development (Terentieva, 2016, p. 1). The radical renewal of directions, principles and mechanisms of educational development in accordance with the modern needs of society and the dynamics of the world educational space, including university education and lifelong learning, is related to ensuring and maintaining people's living standards and the need to meet their evergrowing needs. In the conditions of the integration choice of the state, university education and lifelong education, being the center of reproduction of intellectual potential, become a strategically important subject of ensuring the innovative development of society.

The Aim of the Study is to substantiate the interaction of university education and lifelong learning and to determine their role in the modern European social space.

Theoretical Basis and Methods of Research. In recent years, the study of the problems of university education and lifelong learning has received considerable attention from domestic scientists, among whom it is necessary to emphasize the scientific achievements of N. Avshenyuk, I. Kalenyuk, O. Grishnova. A. Gurzhiy, V. Kremen, V. Lugovoi, L. Lukyanova, N. Nychkalo, O. Savchenko and others, and foreign researchers A. Auzan, K. Flora, M. Marl, M. Murphy, P. Montesinos and others. Researchers paid special attention to the problem of transformation of university education, because in the context of globalization, geopolitics and scientific and technological progress there is a reorientation of its goals and functions, changing not only the duration and forms (Terentieva, 2016), but also conceptual directions, new educational structures, including lifelong learning.

In the process of writing the article, methods of theoretical generalization and analysis were used: comparative analysis; methods of grouping and systematization, which allowed to justify the interaction of university education and lifelong learning in the European educational environment.

Results. Universities today have made significant progress in expanding access and in- creasing opportunities for human education. But the world is changing rapidly, leading to cultural, demographic and technological changes in the educational process. Rethinking social tasks, the need to adapt to society's expectations, the growing demand for the formation skills of the future encourage university education at the beginning of the XXI century to prepare a successful professional (Terentieva, 2016), which focuses on continuous updating and replenishment of knowledge, skills and abilities which today are defined not only as a true indicator of professional development of the specialist, but also becomes an indicator of personal development.

The driving forces behind change and the landscape of the near future are: increasing life expectancy, the development of intelligent technologies, the growth of digital reality, the restructuring of organizations, institutions and businesses, the latest media and social networking technologies, global interconnectedness.

At the same time, it should be emphasized that the construction of a modern university educational environment is possible taking into account the principles of cooperation rather than rivalry, expanding the pedagogy of cooperation (Tovkanets, 2018), emphasis on student independence, including independent planning of research content and learning process, creation of personalized learning trajectories that combine learning in virtual environments (online courses, lectures in virtual reality, social simulators), learning in practice in real life situations, in a cooperative education, etc., building learning around solving real life problems and challenges of civilization, not around academic subjects, providing ergonomic requirements for educational space and technologies that support emotional and creative interaction, flexibility, openness, willingness to accept the new, development and use of game technologies; focus on preparation for research, digital pedagogy (Valencia Center for Quality and Change Management, 2011, p. 80).

UN documents on the adoption of the agenda in the field of sustainable development for the period after 2015 focus on the following goals of university education (UN, 2015):

1. Ensuring equal access to low-cost and high-quality higher education for the entire population by 2030 . 
2. Establishment and improvement of educational institutions that take into account the interests of people with special educational needs and gender aspects, ensuring freedom from violence and social barriers and an effective educational environment for all.

3. Increase the number of scholarships awarded to students from developing countries worldwide by 2020 .

4. Increasing the number of qualified teachers on the basis of international cooperation by 2030 .

Analysis of scientific and documentary sources (Flora, 2016; Laszlo, \& Russell, 2013; Daheim, Wintermann, Glenn, Korn, \& Schoon, 2019) shows that the new educational paradigm necessitates radical changes in the system of university education. To create conditions for new education, it is necessary to supplement the introduction of technological innovations with radical changes in personal and interpersonal aspects of educational systems: growth of personality-oriented education and emphasis on self-organization of student educational activities (Flora, 2016), creation of teams, groups and network (mutual) learning,opportunity to develop collective and global competencies and processes of individual growth, new global educational ecosystems, improvement of educational level indicators.

In recent years, universities have changed their paradigm: they are moving from the classical, research, model to "University 3.0 », in which the «third», after educational and scientific activities, is a completely new activity related to the development of regional communities, that is, the impact of higher education institutions on the economy, the level of human capital development and the innovative potential of the region. If earlier higher education institutions could afford to remain on the periphery of the processes taking place in society, in the modern knowledge economy they have drastically changed their location, being at the epicenter of events. We are also talking about the social responsibility of universities in the context of providing potential clients at the postgraduate level with opportunities to provide appropriate educational services (additional education to improve the professional level, to meet the interests regardless of age).
At the same time it should be emphasized that the mechanism of preservation and reproduction of cultural potential of modern society, the mechanism of preservation and reproduction of professional potential of modern society, one of the determining factors of production development, activator of acceleration of scientific and technological progress, one of the regulators of global and local socio-economic development (with strong adaptive and compensatory reserves) today is lifelong learning, which in conjunction with university education is aimed at the formation of competencies.

Modern research shows that in the context of globalization and transnationalization it is important to form the following competencies (Daheim, Wintermann, Glenn, Korn, \& Schoon, 2019):

1. Personal (general cultural) competencies: an optimistic view of life situations, that is the ability to adapt and interact effectively in the face of growing demands of volatile and uncertain environments, ambiguity of signals and complexity of contexts.

2. Social competencies: data synthesis - the ability to analytically process large amounts of data, read statistics, identify algorithms, predict dynamics; media literacy - the ability to respond quickly, critically evaluate and create content in new media forms, the ability to oppose constructive dialogue to hate speech, to show mental resistance to various forms of propaganda and imposed narratives, willingness to verify facts in many areas of information, effectively engaging audiences for interactivity, maintenance of intensive and convincing communication; transdisciplinarity understanding of concepts at the intersection of several industries, the ability to maintain interdisciplinary dialogue and interact productively in cross-sectoral teams; design thinking - the ability to present and disclose tasks, as well as model optimal work processes and environments to systematically achieve the desired results in each individual situation, identify and stimulate the necessary thinking patterns for each task and the ability to create physical and mental prerequisites for their solution.

3. Analytical competencies: sociability - the ability to establish direct and deep interpersonal relationships, high emotional education and social competence based on trust and re- 
spect as prerequisites for cooperation; transculturalism - the ability to adapt and interact in different environments of the glocalized world, the ability to establish communication in accordance with local specifics both at the level of linguistic understanding and at the level of adaptation to social, cultural, geopolitical context; cyber-engagement - the ability to work productively, to stimulate feedback.

4. Competences of synthesis: meaningmaking - the ability to recognize the causes and consequences of key trends, to notice tendencies on the periphery of social systems; heuristics - the ability to find solutions and answers outside the standard options and prescriptions, awareness of other paradigms and the ability to go beyond the existing paradigm to find answers, inclusive growth, willingness to expand the horizons of planning, flexible thinking and active formation of common intentions to achieve comprehensive goals with other participants in the process; selectivity - the ability to rank and filter information by importance and relevance, the ability to work in multiple scenarios of events in the environment (Despati, 2017).

University education in the European context is seen at the beginning of the XXI century from the standpoint not only as teaching and research, but also as a socially responsible structure whose mission is social responsibility and development of local communities, providing conditions for lifelong learning.

European experts have developed a system that identifies the characteristics and criteria for the effectiveness of higher education (Marhl, \& Pausist, 2011):

1. The criterion «Human Resources» is aimed at identifying the transfer of competencies formed in the process of research in the field of production and provision of public services (social mission). Indicators of this criterion are the quantitative and percentage of graduates with relevant diplomas who got a job in the production and social services.

2. Criterion «Intellectual property» - codification of knowledge produced by the university. Indicators refer to patents registered by both the university and individual inventors, its staff, the number of licenses obtained and the amount received from royalties.

3. Commercialization of the results of individual and collective research, that is, the trans- fer of knowledge through entrepreneurial activity (the presence of target working groups, business incubators, the provision of university funding for companies, including equity participation).

4. Contracts with production, joint production of knowledge and their circulation in the field of production as the main marker of the attractiveness of the university. Indicators can be the number of contracts (with industry), membership in professional associations, the role played by university professionals in professional networks, publications, types of participation in lifelong learning, consulting activities, the number of internships.

5. Contracts with government agencies, social orientation, establishing non-profit relations, focus on socio-cultural sphere (education, tourism, medicine, etc.).

6. Participation in the decision-making process, involvement in the formation and implementation of policy decisions at various levels, inclusion in strategic research, in the official debate on policy in the field of science, technology and innovation; participation in the preparation of long-term programs, involvement in the work of committees for the development of standards, security strategies.

7. Involvement in socio-cultural and social life, the availability of sustainable «resources» used in the socio-cultural life of the city or region (museums, libraries, orchestras, sports facilities), open to students and other residents.

8. The results of knowledge transfer to society, «dissemination of knowledge» and interaction with society as a whole.

Many official and political documents interpret universities as a kind of «driving force of growth» in an economy whose development is due to the accumulation of knowledge. In particular, it is believed that their role in economic development is largely based on the commercialization of research. However, the relationship between universities and the rest of society, in addition to commercial activities, affects many other aspects. Universities contribute to government, public life and the private sector, not only improving financial performance but also the quality of life and social services.

P. Montesinos, J. Carot, F. Mora (2008) identify three driving factors underlying the mission of universities: social, entrepreneurial and innovative (p. 197-198). The social side in- 
cludes activities that do not aim to obtain economic benefits: the provision of social services on a voluntary basis, the formation of social networks, open cultural events at the university. The entrepreneurial aspect consists in the creation of joint production research, commercialization of intellectual property, implementation of paid training programs, rental of premises for exhibitions and conferences. In the innovation direction, the key component is the concept of improvement, examples of which are regional innovation developments, the creation of regional networks with entrepreneurs, the introduction of patents, consulting of government agencies.

Based on the scientific and professional approaches described above, experts have proposed a system of parameters that reflect the specifics of the social mission and relate to certain activities (Marhl, \& Pausist, 2011). The first parameter can be defined as «lifelong learning». This includes higher education and inservice training programs targeted at adult target audiences. The second parameter was «technology and innovation transfer», which involves the exchange of knowledge, including in the context of research. The third parameter is «social involvement» in public life, which involves cooperation between universities and society (at the local, regional, national and global levels) for the purpose of mutually beneficial non-commercial exchange of knowledge and material resources.

The first two parameters are based on the general idea of an «entrepreneurial university» that interacts with society on an economic basis. The third parameter is more related to the role of the university as a provider of social services to society. In particular, public higher education institutions, as non-profit organizations, should have obligations related to participation in ensuring social welfare, which does not always lead to financial benefits for the university, and sometimes is even unprofitable. However, the university has social obligations and must develop activities that enable it to fulfill this special role.

Within the social mission of the university, research becomes a driving force for finding new, more effective economic solutions for society, as well as means of attracting additional funding. Much attention is also paid to continuing education, as the involvement of adult students develops the role of the university as a permanent «lifelong» partner. In most European countries, lifelong learning is becoming one of the activities driven by business factors. Social involvement is less dependent on the financial aspect, but creates a socio-entrepreneurial environment for activities under the «third mission». In any case, new types of services are closely related to the idea of a business university. The analysis showed that modern approaches to the role of university education in the social space are assessed by three parameters: the development of lifelong learning within universities, the exchange of technology and innovation and social inclusion (Valencia Center for Quality and Change Management, 2011).

Strengthening the function of interaction in the structure of social inclusion can be diversified into four key components: in implementing development programs, the university interacts with a wide range of collective actors involved in the development of regional systems, which allows indirect influence and remain in the trend of regional development; the number and quality of connections of the university, which are subsequently formed in the platform of interaction, affect both the university itself and its environment; the university is integrated into the processes of regional development (Auzan, 2013), the growth of its influence is progressive and is expressed in the complexity of the system of interactions of the university; strengthening the interaction of the university on one or another priority of work strengthens its impact on regional development and intensification of lifelong learning.

Conclusions. In the context of the transformation of university education and its gradual adaptation to the needs of society, the question of the need to expand the scope of universities and their going beyond the two-dimensional classical model, which includes educational activities and research. Today, the issue of social purpose of universities, and in their framework and lifelong learning, which is expressed in the integration into the context of regional, national and even international development, which may be prospects for further research. 
Auzan, A.A. (2013). The mission of the university: the view of the economist. URL: http://polit.ru/article/2013/05/07/auzan/

Kalenyuk, I.S. (Eds.). (2011). Integration of higher education in Ukraine into the European and world educational space: economic dimension. Chernihiv: RVC «Desnyanskaya Pravda».

Kremen, V.G, Lugovyi,V.I, Gurzhiy, A.M, \& Savchenko, O.Ya. (2016). National report on the state and prospects of education in Ukraine. Kyiv: Pedagogical thought.

Lukyanova , L.B. (2010) Sociocultural function of adult education in modern society. Bulletin of Cherkasy University, 6-12.

UN. (2015). Draft outcome document of the United Nations summit on the adoption of the post-2015 development agenda. URL: http://www.un.org/ga/search/view

Kalenyuk, I.S., \& Kuklin, O.B. (2012). Development of higher education and knowledge economy. Kyiv: Knowledge.

Terentieva, N.O. (2016). Trends in the development of university education in Ukraine (second half of the XX early XXI century). (Abstract dissertation for the degree of Doctor of Pedagogical Sciences). V. Dahl East Ukrainian National University, Kyiv.

Tovkanets, G.V. (2018). University education in the transformation of society in the XXI century. Nauka, edukacja, wychowanie and praca (s. 244-251). Warsaw-Siedlce: AKKA.

Despati, K. (2017). How to pump your skills for effective interaction with people, technology and the world in the future. URL: https://biggggidea.com/practices/11-navichok-yaki-potribno-opanuvati-do-2020-roku/

Flora, C. (2016). The Golden Age of Teaching Yourself Anything. URL: https://www.psychologytoday.com/intl/articles/201607/the-golden-age-teaching-yourself-anything

Valencia Center for Quality and Change Management. (2011). Final Report of Delfi: Study E3M project European indicators and ranking methodology for university Third Mission (Pr.No143353-LLP-1-2008-1-ES-KAIKAISCR). Valencia, Spain: Center for Quality and Change Management.

Luksha, P., Cubista, J., Laszlo, A., Popovich, M., \& Ninenko, I. (2018). Global Education Futures: Report Educational ecosystems for societal transformation. GEF.

Laszlo, A., \& Russell, J. (2013). Thrivable Education. In E. Laszlo, \& K. Dennis (Eds.), WorldShift 2020: The New Vision. Exploring the Evolving Horizons (pp. 1-8). Rochester, VT: Inner Traditions.

Marhl, M., \& Pausist, A. (2011). Third Mission Indicators for New Ranking Metodologies. Evaluation in Higher Education, 5(1), 43-64.

Montesinos, P., Carot, J-M., \& Mora, F. (2008) Third Mission ranking for world class universities: Beyond teaching and research. Higher Education in Europe, 33(2-3), 195-199.

Daheim, C., Wintermann, O., Glenn, J. C., Korn, J., \& Schoon, C. (2019). 2050: The Future of Work. URL: https://www.bertelsmann-stiftung.de/fileadmin/files/BSt/Publikationen/GrauePublikationen/BST_Delphi_E_03lay.pdf

Ганна Товканець, доктор педагогічних наук, професор, завідувач кафедри теорії і методики початкової освіти Мукачівського державного університету.

Anna Tovkanets, Doctor of Pedagogical Sciences, Professor, The Head of the Department of Theory and Methods of Primary Education, Mukachevo State University.

E-mail: tovkanec2017@gmail.com

ORCID ID 0000-0002-6191-9569

Received: 11.10 .2020

Accepted: 16.11.2020 